\title{
Infiltration and interrill erosion responses to selected live- stock grazing strategies, Edwards Plateau, Texas
}

\author{
THOMAS L. THUROW, WILBERT H. BLACKBURN, AND CHARLES A. TAYLOR, JR.
}

\section{Abstract}

Understanding the temporal response of infiltration rate and interrill erosion to selected livestock grazing strategies is necessary for the continued soil and water conservation of rangeland. Infiltration rate and interrill erosion were sampled bimonthly from 1978-1984 on pastures grazed continuously (MCG) and moderately stocked (8.1 ha AU-1); continuously (HCG) and heavily stocked (4.6 ha AU-1); high-intensity, low-frequency (HILF) and moderately stocked (8-1; 17:119 day, stocked at 8.1 ha $\mathrm{AU}^{-1}$ ); short duration (SDG) and heavily stocked (14-1; 4:50 day, stocked at 4.6 ha AU-1). The MCG and HILF pastures were able to recover from droughts and maintain initial infiltration rates and interrill erosion. In contrast, infiltration rates decreased and interrill erosion increased on HCG and heavily stocked SDG pastures. The trend of infiltration rate and interrill erosion deterioration in the heavily stocked SDG and HCG pastures was not gradual; rather, it followed a stair-step pattern typined by decreasing condition during drought and an inability to recover to pre-drought level during periods of above-normal precipitation. The heavy stocking rate and climate rather than grazing strategy were the primary factors infuencing the hydrologic responses. Infiltration rates were seasonally cyclic in the SDG and HCG pastures, but no significant seasonal trend could be identified in the MCG pasture. This was attributed to greater midgrass cover and litter accumulation in the MCG pasture which provided cover stability compared to less litter accumulation and a greater dominance of seasonal shortgrasses and forbs in the SDG and HCG pastures. Total organic cover was the most important factor determining infiltration rate. The midgrass bunch growth form and litter accumulation were the most important factors influencing interrill erosion. Both factors increased microrelief, and obstructed sediment transport and interrill erosion.

Key Words: grazing systems, midgrass, shortgrass, sediment, runoff

The potential effects of livestock grazing on rangeland hydrology have been studied for many years (literature summarized by Branson et al. 1981, Meeuwig and Packer 1976, Gifford and Hawkins 1978, and Blackburn 1984). However, no continuous longterm research had documented the seasonal hydrologic pattern on rangeland under various grazing strategies and stocking rates. The objective of this research was to assess the seasonal and long-term

\footnotetext{
Authors are currently range research scientist, P.O. Box 2954, Mogadishu, Somalia; hydrologist, USDA-Agricultural Research Service, Northwest Watershed Research Center, 270 South Orchard, Boise, Idaho 83705; and superintendent of the Texas Agricultural Experiment Station at Sonora, Texas 76950. At the time of this rescareh the senior and second authors were graduate research assistant and professor of watershed management at Texas A\&M University, respectively.

This study was a cooperative project between the U.S. Department of Agriculture and Texas Agricultural Experiment Station. Financial support of the Soil Conservation Service RCA Special Study and a Science/Education Grant is acknowledged. The assistance of H.D. Petersen, statistician, USDA-Agricultural Research Service, College Station, Texas, and J.H. Newton, associate professor of statistics, Texas A\&M University, with the experimental design and statistical analysis is acknowledged along with the data collection efforts of Robert Knight (1978-1979) and George McCalla (1980-1981). Special thanks to S.L. Hennefer for typing the manuscript. Published with the approval of the Director, Texas Agricultural Experiment Station as TA-23203, and USDA-Agricultural Research Service, Pacific West Area.

Manuscript accepted 29 February 1988.
}

hydrologic responses of pastures grazed continuously (MCG) and moderately stocked; continuously (HCG) and heavily stocked; high-intensity, low-frequency (HILF) and moderately stocked; and short duration grazing (SDG) and heavily stocked.

Infiltration is the process by which water enters the soil and infiltration rate is the quantity of water absorbed per unit of time. Interrill erosion is the uniform detachment of soil material by raindrop splash and sheet flow. The extent to which livestock grazing affects the amount and type of vegetation also influences the infiltration rate and interrill erosion. Vegetation cover and standing crop are generally related positively to infiltration rate and negatively to interrill erosion (Rauzi et al. 1968, Blackburn 1984, Wood and Blackburn 1981, McGinty et al. 1979, McCalla et al. 1984).

Vegetation growth form is an important determinant of infiltration rate and interrill erosion. Infiltration rates are usually highest and interrill erosion lowest under trees and shrubs followed in decreasing order by midgrass (bunchgrass), shortgrass (sodgrass), and bare ground (Blackburn 1975, Wood and Blackburn 1981, Knight et al. 1984, Thurow et al. 1986). Thus, infiltration rate and soil erosion are affected by livestock grazing frequency and intensity to the extent that grazing affects the amount and type of plant cover and physically impacts the soil (Smith 1967, Skovlin et al. 1976, Rhoades et al. 1964, Hanson et al. 1973, Ellison 1960, Blackburn 1975, Thurow et al. 1986, 1988, Warren et al. 1986a, 1986b).

\section{Materials and Methods}

\section{Study Area and Treatments}

Research was conducted at the Texas Agricultural Experiment Station which is located in Edwards and Sutton counties $\left(31^{\circ} \mathrm{N}\right.$; $100^{\circ} \mathrm{W}$ ) approximately $56 \mathrm{~km}$ south of Sonora, at an elevation of $632 \mathrm{~m}$ on level to gently sloping terrain $(<3 \%)$. The mean frost free period is $\mathbf{2 4 0}$ days. Annual precipitation at the station is highly variable in amount (annual median precipitation, 1918-1984 = 438 $\mathrm{mm}$; range $=156$ to $1,054 \mathrm{~mm}$ ) and events vary seasonally. In general, March-July 1978, April-August 1980, and April-September 1983 were periods of drought and September 1980 through August 1982 was a period of well-distributed, greater than median precipitation.

Soils in the study pastures were Tarrant silty clays and soil depth overlaying a fracture limestone substrate ranged from about 150 to $450 \mathrm{~mm}$. Textures of this clayey-skeletal, montmorillonitic, thermic family of Lithic Haplustalls ranged from silty clay loam to clay. There was no consistent mean textural difference between the soils of the SDG/HILF, MCG, and HCG pastures.

Vegetation in the pastures is characterized as an oak-grassland community with a clustered woody plant distribution (Smeins et al. 1976). Prior to the grazing treatments, the study site was characterized as being dominated by either oak mottes, midgrasses, or shortgrasses. Oak mottes dominated $27 \%$ of the study site and were composed primarily of live oak (Quercus virginiana Mill.). Midgrasses dominated $30 \%$ of the study site with the primary species being sideoats grama (Bouteloua curtipendula (Michx.) Torr.), Texas wintergrass (Stipa leucotricha Trin. and Rupr.), and threeawn (Aristida spp.). Shortgrasses, primarily curlymesquite (Hilaria belangeri (Steud.) Nash), dominated $43 \%$ of the study site. 
During January 1978, three 6-ha study pastures were established by subdividing a larger pasture that had been stocked at a moderate continuous rate of about 8.1 ha $\mathrm{AU}^{-1}$ since 1949. Treatments established were: (1) a continuously grazed (MCG) strategy moderately stocked at 8.1 ha $\mathrm{AU}^{-1}$; (2) a continuously grazed (HCG) strategy heavily stocked at $4.6 \mathrm{ha} \mathrm{AU}^{-1}$; and (3) a high-intensity, low-frequency (HILF) pasture used to simulate an 8 pasture rotation grazing strategy (8-1; 17:119 day) (nomenclature and notation follow Kothmann 1974) moderately stocked at 8.1 ha $\mathrm{AU}^{-1}$. During January 1980 , the HILF strategy pasture was changed to a short duration grazing strategy (SDG) $(14-1 ; 4: 50$ day) and stocked heavily at $4.6 \mathrm{ha} \mathrm{AU}^{-1}$. Initially the $\mathrm{HCG}$ pasture was continuously stocked at 1 ha $\mathrm{AU}^{-1}$ for 5 months before the stocking rate was reduced to $4.6 \mathrm{AU}^{-1}$. The stocking rate of the HCG and SDG pastures averaged 1.76 times that of the moderately stocked pastures. Even though the stocking rates were similar in the HCG and SDG pastures, grazing pressure index was greater in the SDG pasture. An animal unit ratio of $50 \%$ cattle, $25 \%$ sheep, and $25 \%$ goats was used on the HILF/SDG and HCG pastures. Due to the small pasture size, the 50:25:25 grazing ratio could not be precisely maintained in the MCG pasture. Sheep and goats were grazed continuously with a cow grazed intermittently to maintain the moderate stocking rate.

\section{Methods}

The study sites' grazing history, soil, vegetation, and hydrology were similar prior to study initiation in 1978. Infiltration rate and interrill erosion of the site prior to this study were similar within vegetation types. Pretreatment infiltration rates after 30 minutes averaged $198 \mathrm{~mm} \mathrm{~h}^{-1}$ for the midgrasses and $138 \mathrm{~mm} \mathrm{~h}^{-1}$ for the shortgrasses. Interrill erosion averaged $15 \mathrm{~kg} \mathrm{ha}^{-1}$ from midgrass and $187 \mathrm{~kg} \mathrm{ha}^{-1}$ from shortgrass sites (Knight 1980, Knight et al. 1984).

Infiltration rates, interrill erosion, cover characteristics, vegetation standing crop, mulch accumulation, and surface soil physical properties of grass interspaces were sampled bimonthly from March 1978 through March 1984. Sample locations were randomly assigned to gridded areas within each pasture prior to initiating the grazing strategies. Areas adjacent to fences and watering locations were excluded due to differential livestock use patterns associated with these structures. During each sample period ten $0.45 \mathrm{~m}^{2}$ plots were randomly assigned to midgrass and shortgrass sites within the gridded areas. This sampling sequence prevented destructively sampling any one area more than once. During July 1980 the sample size was reduced from 10 to 8. Due to the scarcity of midgrass plants in the HCG pasture, sampling of those plants was discontinued after May 1980.

Plots were pre-wet by applying 100 liters of water via a mist-type nozzle over a $1.1-\mathrm{m}^{2}$ circular area. The water was dispensed under a plastic cone from the mist-type nozzle located $0.6 \mathrm{~m}$ above the soil. The nozzle delivered $30 \mathrm{lh}^{-1}$ with a pressure of $2,737 \mathrm{~Pa}$. After the water was applied, the plots were covered with plastic for about 24 hours. This procedure was used to reduce the variability in antecedent soil moisture that would have occurred between sample dates and thus facilitated analysis of trends across time. A drip-type rainfall simulator (Blackburn et al. 1974) was used throughout the study. The simulator raindrops were $2.5 \mathrm{~mm}$ in diameter. Drops falling $2.1 \mathrm{~m}$ reach $5.25 \mathrm{~m} / \mathrm{sec}$ or $71 \%$ of the terminal velocity achieved by raindrops in an unlimited fall (Laws 1941).

The simulated rainfall was applied at a rate of $203 \mathrm{~mm} \mathrm{~h}^{-1}$ for 30 min. Storms of this intensity, but for shorter durations, occur every year or two. This rainfall rate was chosen so that all plots would reach a terminal infiltration rate. This criterion was desirable so that terminal infiltration rates could be compared between the grazing treatments, midgrass, and shortgrass growth forms. Because of the rocky soil, flexible bands were used to create runoff test plots that ranged in area from $0.25 \mathrm{~m}^{2}$ to $0.53 \mathrm{~m}^{2}$ and averaged $0.45 \mathrm{~m}^{2}$. Plot area was determined by mapping each plot using a gridded frame. Runoff was continuously collected from each plot and was

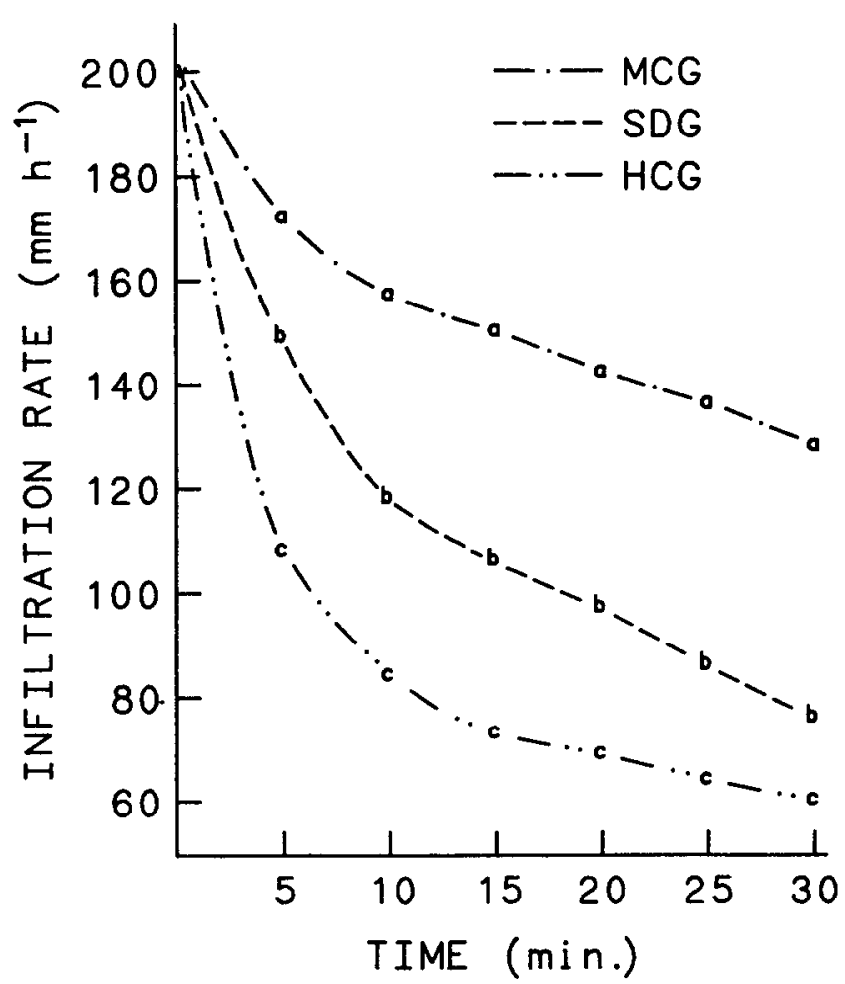

Fig. 1. Infiltration rate means across the 30 minute simulated rainfall sample for January 1984, Edwards Plateau, Texas. Grazing treatment means with the same letter for the same sample date are not significantly different $(\mathbf{p}<0.05)$.

recorded by weight at 5-min intervals. Infiltration rates were determined by calculating the difference between applied volume of simulated rainfall and the runoff. The influence of interception on infiltration rates was not considered to be a significant source of water loss and therefore was ignored (Thurow et al. 1987).

A l-liter subsample of thoroughly mixed runoff was taken at the conclusion of the 30-minute sample period. Each subsample was filtered through a tared $\# 1$ Whatman filter. Sediment remaining on the filter was oven-dried, weighed, and converted to sediment production $\left(\mathrm{kg} \mathrm{ha}^{-1}\right)$ based on the area and total runoff from each plot and used as an index of interrill erosion.

The foliar cover in each infiltration plot of midgrass, shortgrass, forbs, litter, rock ( $>2 \mathrm{~mm}$ ) and bare ground was determined by ocular estimate. Standing grass (live and dead) and standing forbs were clipped and litter was collected from each plot, dried at $60^{\circ} \mathrm{C}$ for $48 \mathrm{~h}$, weighed, and converted to $\mathrm{kg} \mathrm{ha}^{-1}$.

The surface roughness of each plot was measured with a relief meter (a frame with a set of 10 pins placed $60 \mathrm{~mm}$ apart) (Kincaid and Williams 1966). A representative surface toughness index was obtained by measuring the relief of 3 different lines across each plot and then calculating the standard deviation of the pin heights.

Soil cores were taken at the 0 to $30 \mathrm{~mm}$ and 50 to $80 \mathrm{~mm}$ depths adjacent to each plot prior to the initiation of the simulated rainfall. Soil bulk density was determined by the core method (Black 1965 ) and soil water content by the gravimetric method (Gardner 1965).

A soil sample of the surface $50 \mathrm{~mm}$ was taken from each plot after the simulated rainfall test. Organic carbon was determined by the Walkley-Black method (Walkley and Black 1934), aggregate stability by the wet sieve method (Kemper and Koch 1965), and soil texture by the hydrometer method (Bouyoucos 1962).

In July 1978,3 natural rainfall and runoff plots $(1.8 \mathrm{~m}$ wide and $22.1 \mathrm{~m}$ long) were established in each of the pastures to obtain 


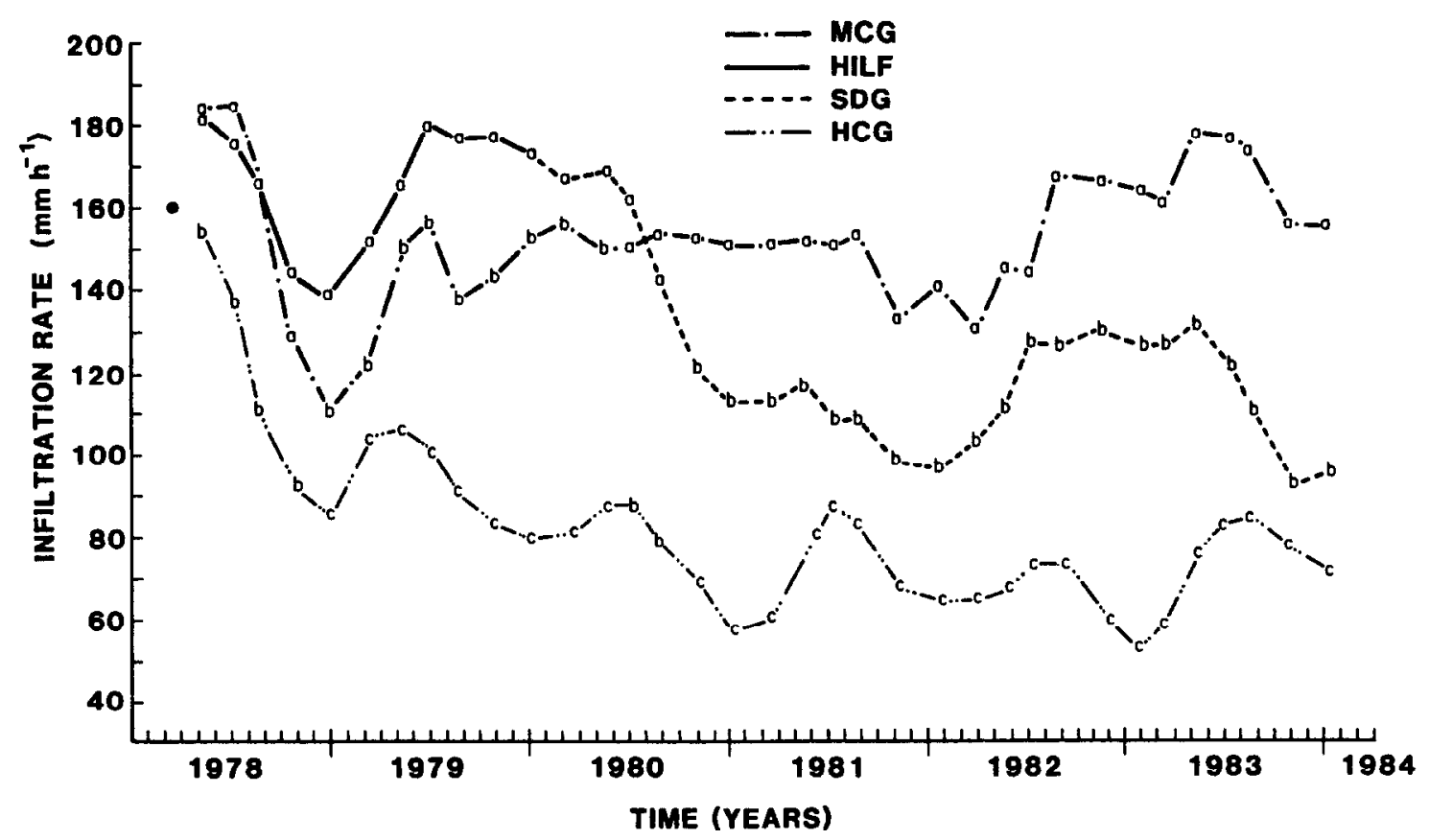

Fig. 2. Mean infiltration rate $\left(\mathrm{mm} \mathrm{h}^{-1}\right)$ after 30 minutes of simulated rainfall, Edwards Plateau, Texas. Grazing treatment means with the same letter for the same sample date are not significantly different $(p<0.05)$. The dot $(0)$ indicates the composite sample value for March 1978.

independent verification of the data collected on the simulated rainfall plots and to obtain an estimate of rill and interrill erosion. The slope of the plots ranged from 1 to $2 \%$. A measurement of runoff volume was collected from 15 storms and a thoroughly mixed subsample of the runoff from each storm was used to determine rill and interrill erosion (lab procedure was the same as for the simulated rainfall and sediment determination). Three permanent $0.25-\mathrm{m}^{2}$ vegetation plots were designated in each of the natural runoff plots. A 10-point frame (Brown 1954) was used bimonthly to measure foliar and basal cover on each plot. A total of 270 canopy points and 270 basal points was recorded for each pasture. Changes in midgrass and shortgrass cover were also assessed on a pasture-wide basis using the step-point method. Five hundred points in each pasture were sampled once each August from 1978 through 1984. Meterological data were collected at a permanent station located $1 \mathrm{~km}$ east of the study pastures.

\section{Analyses}

Data were tested for normality using skewness and kurtosis analysis (Snedecor and Cochran 1971). Because values for sediment and surface roughness were highly skewed, they were transformed using $\log _{10}$ before analysis. Correlation analysis was con-

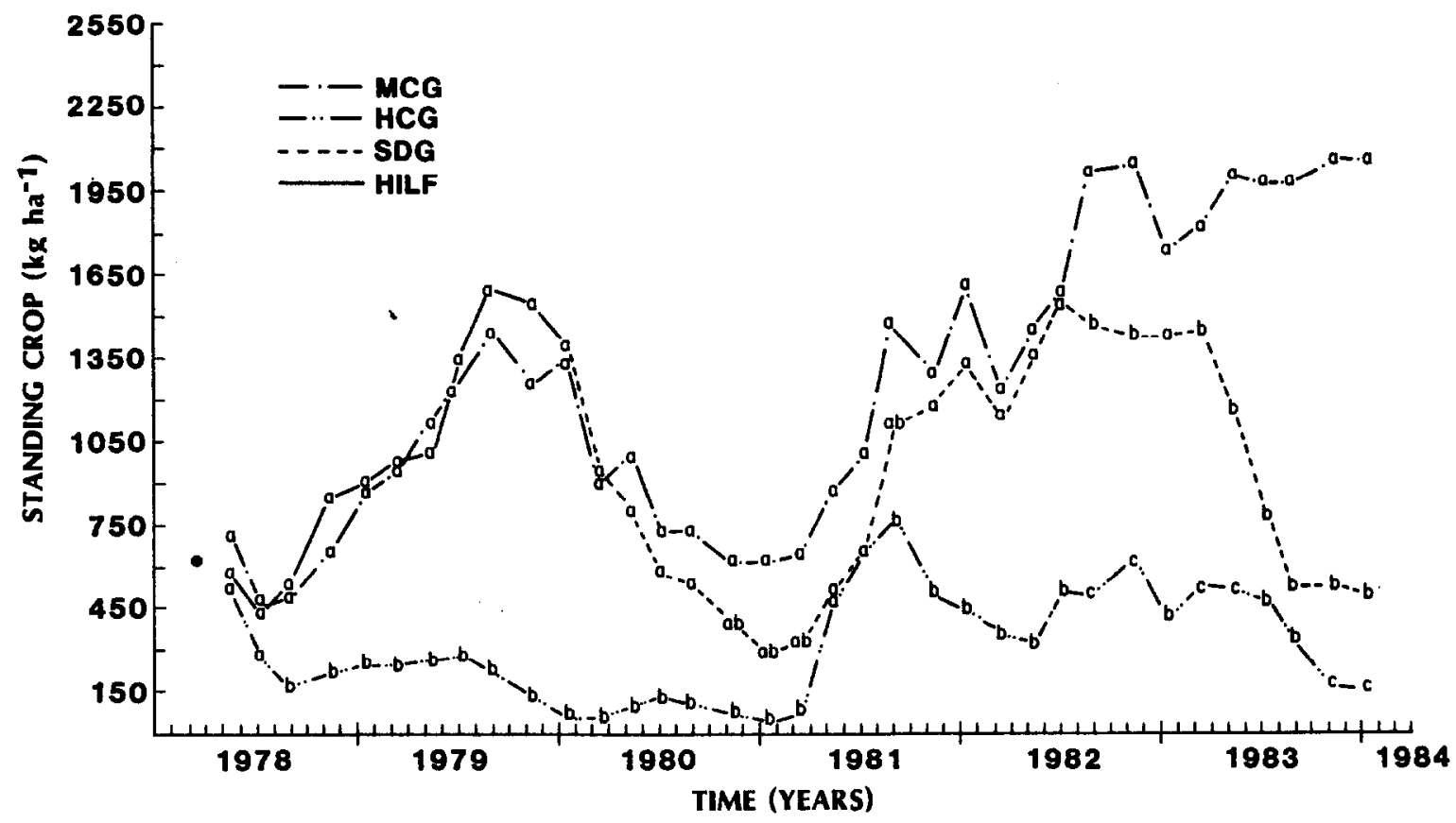

Fig. 3. Standing crop $\left(\mathrm{kg} \mathrm{ha}^{-1}\right)$ on simulated rainfall plots, Edwards Plateau, Texas. Grazing treatment means with the same letter for the same sample date are not significantly different $(p<0.05)$. The dot $(\bullet)$ indicates the composite sample value prior to starting the treatment, March 1978 . 
ducted by testing regularly spaced discrete classes of the dependent variable against the independent variable median value for each of those classes. In all cases, the minimum class size was composed of a median of at least 60 samples. The number of classes used for the correlation test of a dependent variable ranged from 9 to 20 . Correlation analyses were used to assess the degree of linear association of the variables. Stepwise multiple regression analysis was used to identify the variables that most influenced infiltration rates and interrill erosion (Draper and Smith 1981). Differences between grass growth forms and grazing strategy were tested by analysis of variance. Grazing strategies were not replicated and the error term in the analysis of variance consisted of the nested variation of the randomized sites within the grazing strategies (Dunn and Clark 1974). Treatment means were separated by Duncan's multiplerange test (Duncan 1955). Significant levels were determined at $p<0.05$. Time series analysis was used to determine if infiltration rate followed a seasonally cyclic pattern. Analysis was conducted using the SAS procedure of Newton (1982).

Figures 2, 3, and 6 display running average of 3 sample dates. This procedure aided in graphic display of long-term trends by smoothing variation of individual sample dates that may have resulted from natural site diversity. Data were graphed as a weighted composite of the midgrass- and shortgrass-dominated plots. The composite was formed by weighting the percentage of the midgrass- and shortgrass-dominated areas in each pasture using the data from the pasturewide step-point transects. The percentage of midgrass- and shortgrass-dominated areas was updated by treatment on a March-to-March basis.

\section{Results and Discussion}

\section{Infiltration}

Throughout the study runoff occurred on $98 \%$ of the plots during the simulated rainfall event and terminal infiltration rates were achieved for $95 \%$ of the plots (i.e., when the 25 -and 30 -minute infiltration rates were not significantly different). After November 1980 , the infiltration rates for the 3 grazing treatments were significantly different from each other for all time periods after 5 minutes. The infiltration rate was usually greater in the MCG pasture, intermediate in the SDG pasture, and lowest in the HCG pasture. General shapes of the infiltration rate curves after November 1980 were similar to the January 1984 curves after 6 years of livestock grazing (Fig. 1). Mean infiltration rates for each 5-minute interval had similar trends when correlated with other plot variables; however, the mean infiltration rate after $\mathbf{3 0}$ minutes always had the strongest correlations. Therefore, only the mean infiltration rate after 30 minutes will be discussed. Unless stated otherwise, the infiltration rate refers to the mean infiltration rate established after 30 minutes of simulated rainfall.

Initially, the infiltration rates of the 3 treatment pastures were similar and are indicated by the dot in Figure 2; however, the infiltration rates diverged over time. During the study infiltration rates remained consistently high in the MCG pasture after 1980. The decline in 1978 was the result of a drought that began prior to the onset of spring grass growth and lasted through July. In contrast, the 1980 and 1983 drought began about 6 weeks after the onset of grass growth.

During the 1978 drought the infiltration rates and standing crop in all pastures declined (Figs. 2 and 3). By 1979 a new lower infiltration rate was established in the HCG pasture with slight infiltration rate increases occurring during periods of peak standing crop (Fig. 3).

The heavily stocked SDG (changed from HILF system in January 1980) and HCG pastures during the 1980 and 1983 droughts had a marked decline in infiltration rate. However, during this period the infiltration rate of the MCG pasture remained consistently high. This varied response is in contrast to the 1978 response when the infiltration rate of all 3 pastures declined. The 3 droughts began at different times of the year and thus had different effects on growth. The 1978 drought began prior to initiation of warm season grass growth. The magnitude of drop in infiltration rate during the drought reflected the effect of stocking rate and grazing strategy. The HILF pasture with its 119-day rest period allowed the drought-stressed vegetation time to maintain and recover between grazing periods. The 1980 and 1983 droughts began after the warm-season grasses initiated growth which apparently maintained the infiltration rate in the MCG pasture. However, midgrass foliar cover was essentially eliminated during the first 2.5 years under the HCG strategy and was reduced by approximately onehalf from 1980 to 1984 under the heavily stocked SDG pasture (Thurow et al. 1988), causing infiltration rates to decrease.

Precipitation during 1981 and 1982 was above normal. By the 1983 drought, infiltration rates of the MCG pasture had increased to the rate at the beginning of the study. Climate and stocking rate rather than grazing strategy were the 2 primary causal agents of change. Climate and stocking rate were attributed to the primary causes of seasonal variation in infiltration rate due to their effects on total organic cover (percent ground cover provided by living and dead organic matter). Total organic cover was the variable most closely correlated with infiltration rate $\left(R^{2}=0.96\right.$ for 19 median infiltration rate classes; $r=0.59$ for all 1933 data points) (Fig. 4).

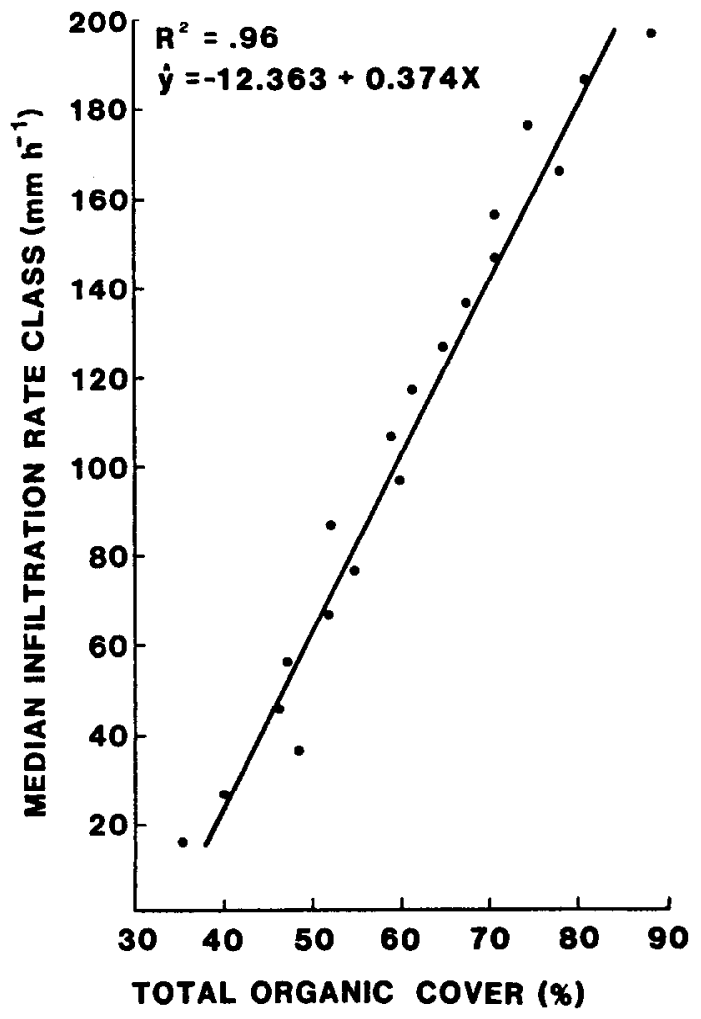

Fig. 4. Relationship of 19 median infiltration rate classes with total organic cover (\%), Edwards Plateau, Texas.

Time series analysis indicated a significant seasonally cyclic pattern in the infiltration rate of the HCG and HILF/SDG pastures, but no significant seasonally cyclic pattern in the MCG pasture. The infiltration rate of the HCG pasture remained within the seasonally cyclic pattern that was established after the response to the 1978 and 1980 droughts. The infiltration rate of the heavily stocked SDG pasture remained in the seasonally cyclic pattern that was established after the response to the 1980 drought. Both moderately stocked HILF and MCG strategies allowed infiltration rates to increase to predrought levels, while the heavily stocked SDG and HCG strategies did not. Two possible explanations exist for the lack of infiltration rate recovery under the heavily stocked 
SDG and HCG strategies: (1) species composition change; and (2) inability to restore grass basal cover and allow litter accumulation (Thurow et al. 1988).

There was a clear decline of midgrass dominance in both the SDG and HCG pastures during the study (Table 1). In contrast,

Table 1. Relative dominance (\%) of midgrass and shortgrass species in the pastures grazed continuoudy (MCG) and moderately stocked; continuously (HCG) and heavily stocked; high-intensity, low-frequency (HILF) and moderately stocked; short duration (SDG) and heavily stocked, Edwards Piatean, Texas.

\begin{tabular}{|c|c|c|c|c|c|c|}
\hline & \multicolumn{2}{|c|}{ MCG } & \multicolumn{2}{|c|}{ HILF/SDG } & \multicolumn{2}{|c|}{ HCG } \\
\hline & $\begin{array}{l}\text { Mid- } \\
\text { grass }\end{array}$ & $\begin{array}{l}\text { Short- } \\
\text { grass }\end{array}$ & $\begin{array}{l}\text { Mid- } \\
\text { grass }\end{array}$ & $\begin{array}{c}\text { Short- } \\
\text { grass }\end{array}$ & $\begin{array}{l}\text { Mid- } \\
\text { grass }\end{array}$ & $\begin{array}{l}\text { Short- } \\
\text { grass }\end{array}$ \\
\hline 1978 & 38.2 & 61.8 & 37.0 & 63.0 & 35.6 & 64.4 \\
\hline 1979 & 37.6 & 62.4 & 33.7 & 66.3 & 28.8 & 71.2 \\
\hline 1980 & 42.1 & 57.9 & 37.8 & 62.2 & 10.0 & 90.0 \\
\hline 1981 & 47.7 & 52.3 & 30.5 & 69.5 & 3.3 & 96.7 \\
\hline 1982 & 47.2 & 52.8 & 33.9 & 66.1 & 3.1 & 96.6 \\
\hline 1983 & 39.7 & 60.3 & 25.1 & 74.9 & 6.1 & 93.9 \\
\hline 1984 & 43.1 & 56.9 & 15.3 & 84.7 & 1.4 & 98.6 \\
\hline
\end{tabular}

there was a slight increase in midgrass dominance in the MCG pasture. The increase in MCG pasture midgrass dominance occurred primarily in 1981 and 1982 . Both 1981 and 1982 were years with above-average precipitation. In contrast, a steady decline of midgrass dominance in the SDG and HCG pastures reflected the inability of midgrasses to maintain themselves under the heavier grazing pressure. This shift in species composition affected total cover because the midgrass bunch growth form was more persistent during winter or drought-induced dormancy than the stoloniferous shortgrass cover which quickly deteriorated when dormant (Thurow et al. 1988). The trait of shortgrass cover to rapidly decline during periods of dormancy and rapidly increase during warm, moist periods caused infiltration rates to seasonally fluctuate in SDG and HCG pastures dominated by shortgrasses. Midgrass cover fluctuated relatively little between seasons (Thurow et al. 1988); therefore, pastures with a well-mixed composition of midgrass and shortgrass species did not show major seasonal fluctuations in infiltration rate.

\section{Interrill Erosion}

Natural rainfall events of approximately $19 \mathrm{~mm}$ or greater produced runoff from the $1.8 \mathrm{~m}$ wide by $22.1 \mathrm{~m}$ long plots. An average of 9 runoff events per year occurred from 1978 through 1983 . Mean annual runoff as a percentage of annual precipitation was $9.8 \%$, $2.9 \%, 2.3 \%$, and $5.1 \%$ for the HCG, MCG, HILF, and SDG pastures, respectively. These percentages are similar to data collected from 1974 through 1976 from 3 nearby watersheds ranging in size from 1.5 to $4.0 \mathrm{ha}$. Runoff as a percentage of precipitation was $3.5 \%$ from a watershed under a moderately stocked 4 pasture deferred rotation strategy and $10.5 \%$ for 2 watersheds under a HCG strategy (Smeins 1977). Mean annual rill and interrill erosion from the runoff plots was $700 \mathrm{~kg} \mathrm{ha}^{-1}$ for the HCG pasture, $250 \mathrm{~kg}$ $\mathrm{ha}^{-1}$ for the MCG pasture, $120 \mathrm{~kg} \mathrm{ha}^{-1}$ for the HILF pasture and $563 \mathrm{~kg} \mathrm{ha}^{-1}$ for the SDG pasture. These values, although much lower than from the simulated rainfall plots, were proportionally similar to the relationship observed between grazing strategy and the simulated rainfall plots.

Litter accumulation $\left(r=-0.98\right.$, for 9 median $\log _{10}$ interrill erosion classes; $r=0.53$ for all 1933 data points) (Fig. 5) was the variable most closely correlated with interrill erosion. When the 9 discrete interrill erosion classes were analyzed, the following model $\left(R^{2}=0.96\right)$ was generated: $\log _{10}$ sediment production $=3.89-0.05$ (midgrass cover) - 0.01 (litter accumulation). Both litter biomass and bunchgrass represent significant obstruction to runoff. By slowing and diverting surface flows, the runoff sediment transport

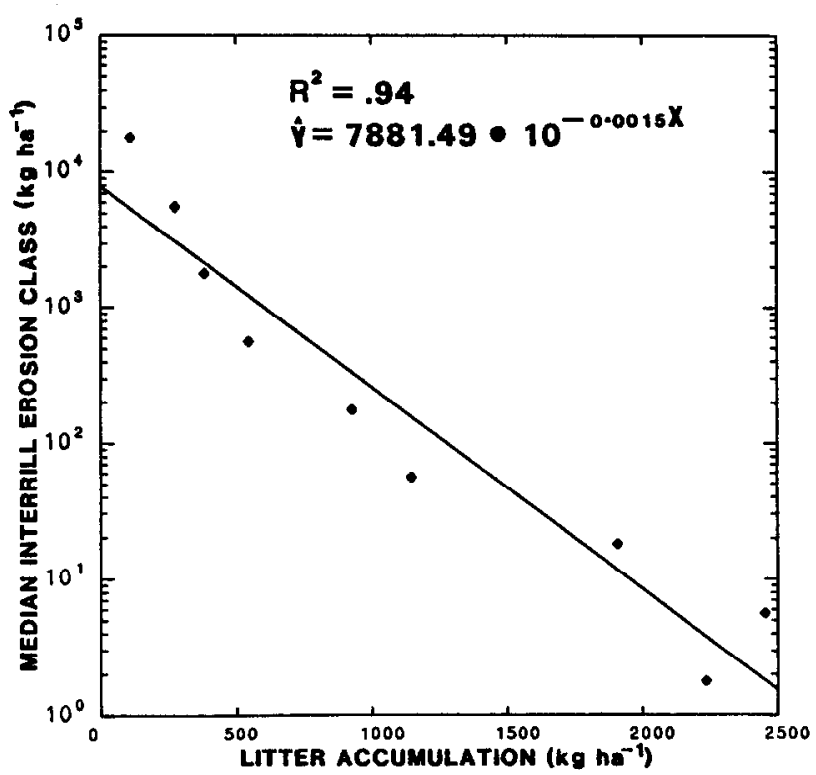

Fig. 5. Relationship of 9 median Log 10 interrill erosion classes with litter accumulation, Edwards Plateau, Texas.

capacity was reduced, causing a portion of the sediment load to be deposited. Total organic cover was also an important factor in interrill erosion because cover broke the impact of raindrops and thus reduced raindrop impact.

Bulk density changed little during the study and was negatively correlated with midgrass cover $(r=-0.78)$, and poorly correlated with shortgrass cover $(r=-0.36)$. Likewise, aggregate stability was positively correlated with midgrass cover $(r=0.78)$ and poorly correlated with shortgrass cover $(r=-0.31)$. The consistent difference of more favorable soil structure associated with midgrasses may possibly be attributed to a more favorable microhabitat for micro-organisms, differential trampling because livestock step around bunchgrass clumps (Balph and Malechek 1985), or more favorable rooting benefits from bunchgrasses that were not detected in the organic matter measurements.

Initially, interrill erosion for the 3 treatment pastures was similar and is indicated by the dot in Figure 6. Unlike infiltration rate, interrill erosion did not follow a seasonally cyclic pattern. Interrill erosion in the HCG pasture soon diverged from HILF and MCG pastures and remained high, although variable throughout the study. The sharp decline in interrill erosion of the HCG pasture in the 1981 growing season coincided with the rapid increase of forbs (mainly bitterweed Hymenoxys adorata D.C.)(Thurow et al. 1988) and shortgrass. This increase in vegetation was temporary and, consequently, the erosion returned in 1982 to a level similar to that of 1980 .

Interrill erosion in the HILF and MCG pastures was similar until late into the 1980 drought and after the HILF pasture was changed to the heavily stocked SDG system. By November 1980, only 10 months after initiation of the SDG system, the interrill erosion from this pasture was significantly greater than from the MCG pasture. Interrill erosion in the SDG pasture remained greater than in the MCG pasture throughout the remainder of the study. A second increase in interrill erosion of the SDG pasture occurred during the 1983 drought. Infiltration rates and erosion of the heavily stocked SDG pasture approached that in the HCG pasture after only 4 years of treatment.

The lack of a full interrill erosion reduction after increases during the 1980 and 1983 droughts in the SDG pasture and the 1978 drought in the HCG pasture implies that changes occurred during these periods from which the pastures did not recover. These rapid, sustained changes in interrill erosion coincided with 


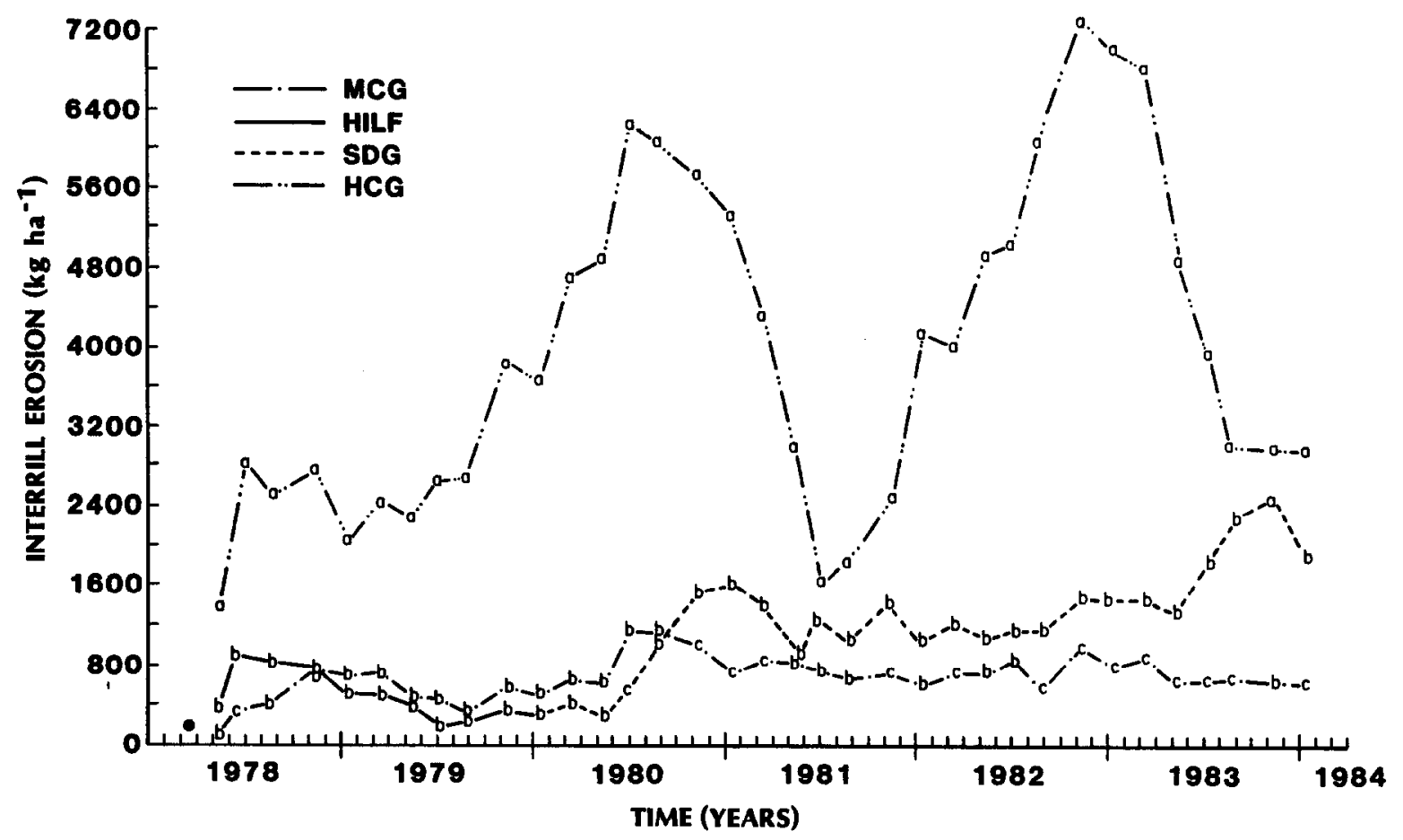

Fig. 6. Mean interrill erosion ( $\mathrm{kg} \mathrm{ha}^{-1}$ ) after 30 minutes of simulated rainfall, Edwards Plateau, Texas. Grazing treatment means with the same letter for the same sample date are not significantly different $(p<0.05)$. The dot $(\bullet)$ indicates the composite sample value for March 1978.

drought and were located on heavily stocked pastures. During drought the grazing pressure on these pastures reduced grass basal cover (Thurow et al. 1988). The high crowns of bunchgrass made them susceptible to damage from heavy grazing pressure (Sims et al. 1982). The litter base of the heavily grazed pastures also declined during drought due to more complete consumption of forage. The continued heavy stocking rate after drought was sufficient to prevent a sustained recovery of total basal cover, litter, and midgrass cover to predrought levels. Thus, increases in erosion occurred in a stair-step fashion rather than a gradual increase.

\section{Conclusions}

During the study infiltration rates decreased and interrill erosion increased in the heavily stocked SDG and HCG pastures. Deterioration of infiltration and interrill erosion rates in these heavily stocked pastures tended to follow a stair-step pattern typified by decreasing grass basal cover, litter, and midgrass cover during drought, and an inability to recover to predrought levels during periods of above-normal precipitation. Conversely, infiltration and interrill erosion rates in the moderately stocked HILF and MCG pastures were able to recover from droughts and maintain initial or improved rates during periods of above-normal precipitation.

Infiltration rates were seasonally cyclic in the heavily stocked SDG and HCG pastures, with no significant seasonal trend identified in the MCG pasture. The shift from a mixed midgrass and shortgrass species composition to predominantly shortgrasses in the SDG and HCG pastures affected total cover because the bunch growth form of midgrasses was more persistent during winter or drought-induced dormancy than the stoloniferous shortgrass cover which quickly deteriorated when dormant. This characteristic of shortgrass cover to decline rapidly during dormant periods and quickly increase during warm, moist periods caused infiltration rates to seasonally fluctuate in the SDG and HCG pastures dominated by shortgrasses. Pastures with a favorable midgrass and shortgrass species composition did not show major seasonal fluctuations in infiltration rate. Unlike infiltration, interrill erosion during the study did not follow a seasonally cyclic pattern.

Considering the short-term (seasonal or $<2$ year) response, total organic cover of the study area was the most important factor determining infiltration and erosion rates. However, over the longterm, the livestock grazing induced shifts in plant composition between bunch and short grasses have the greatest potential to influence infiltration and soil erosion. The midgrass bunch growth form and litter accumulation were the most important factors influencing interrill erosion. Both factors increased microrelief and obstructed sediment transport and interrill erosion.

The heavy stocking rate and climate rather than grazing strategy were the primary factors influencing the hydrologic responses. Heavily stocked SDG or HCG strategies may increase forage utilization (Ralph 1983), but are not suited for long-term soil and water conservation in the Edwards Plateau. The moderately stocked HILF or MCG strategies appear appropriate for conservation of long-term hydrologic condition of the Edwards Plateau.

\section{Literature Cited}

Balph, D.F., and J.C. Malechek. 1985. Cattle trampling of crested wheatgrass under short-duration grazing. J. Range Manage. 38:226-227.

Black, C.A. (ed.). 1965. Methods of soil analysis. Amer. Soc. Agron. Series No. 9, Madison.

Blackburn, W.H. 1975. Factors influencing infiltration and sediment production of semiarid rangelands in Nevada. Water Resour. Res. 11:929-937.

Blackburn, W.H. 1984. Impacts of grazing intensity and specialized grazing systems on watershed characteristics and responses, p. 927-983. In: Developing Strategies for Rangeland Management. Nat. Res. Council/Nat. Acad. Sci., Westview Press, Boulder.

Blackburn, W.H., R.O. Meeuwig, and C.M. Skau. 1974. A mobile infiltrometer for use on rangeland. J. Range Manage. 27:322-323.

Bouyoucos, G.J. 1962. Hydrometer method improved for making particle size analysis of soil. Agron. J. 54:464-465.

Branson, F.A., G.F. Gifford, and J.R. Owen. 1972. Rangeland hydrology. Range Sci. Ser. No. 1 Soc. Range Manage. Denver, Colo.

Brown, D. 1954. Methods of surveying and measuring vegetation. Commonwealth Bureau of Pastures and Field Crops. Hurley, England. Bull. 42. 
Draper, N.R., and H. Smith. 1981. Applied regression analysis. John Wiley and Sons, Inc., New York.

Duncan, D.B. 1955. Multiple range and multiple F test. Biom. 11:1-42.

Dunn, O.J., and V.A. Clark. 1974. Applied statistics: Analysis of variances and regression. John Wiley and Sons, Inc., New York.

Ellison, L. 1960. Influence of grazing on plant succession of rangelands. Bot. Rev. 26:1-78.

Gardner, W.H. 1965. Water content, p. 82-125. In: C.A. Black (ed.), Methods of soil analysis. Amer. Soc. Agron., Agron. Ser. No. 9, Madison.

Gifford, G.F., and R.H. Hawkins. 1978. Hydrologic impact of grazing on infiltration: A critical review. Water Resour. Res. 14:305-313.

Hanson, C.L., H.G. Heinemann, A.R. Kuhlman, and J.W. Neuberger. 1973. Sediment productions from small rangeland watersheds in western South Dakota. J. Range Manage. 26:215-219.

Kemper, W.D., and E.J. Koch. 1965. Aggregate stability of soils from western portions of the U.S. and Canada. USDA Tech. Bull. 1355.

Kincaid, D.R., and G. Williams. 1966. Rainfall effects on soil surface characteristics following range improvements. J. Range Manage. 19:346351.

Knight, R.W.1980. Hydrologic response of selected grazing systems on the Edwards Plateau. Ph.D. Diss., Texas A\&M Univ., College Station. (Diss. Abstr. 41:2425).

Knight, R.W., W.H. Blackburn, and L.B. Merrill. 1984. Characteristics of oak mottes, Edwards Plateau, Texas. J. Range Manage. 37:534-537.

Kothmann, M.M. 1974. Grazing management terminology. J. Range Manage. 27:326-327.

Laws, J.O. 1941. Measurement of the fall-velocity of water-drops and raindrops. Trans. Amer. Geophys. Union 22:709-721.

McCalla, G.R., W.H. Blackburn, and L.B. Merrill. 1984. Effects of livestock grazing on sediment production, Edwards Plateau of Texas. J. Range Manage. 37:291-294.

McGinty, W.A., F.E. Smeins, and L.B. Merrill. 1979. Influence of soil. vegetation and grazing management on infiltration rate and sediment production of Edwards Plateau rangeland. J. Range Manage. 32:33-37.

Meeuwig, R.O., and P.E. Packer. 1976. Erosion and runoff on forest and rangelands, p. 106-116. In: Proc. of Fifth Workshop of the United States/Australia Rangelands, Boise, ID.

Newton, H. 1982. Introduction to the method of time series analysis in the time and frequency demonstration: $A$ user's guide to the timesboard computing library. Dept. of Statistics, Texas A\&M Univ., College Station.

Ralph, M.H. 1983. Vegetation and livestock response to increased stocking rates in a simulated short-duration grazing system. Ph.D. Diss., Texas A\&M Univ., College Station. (Diss. Abstr. 45:21)
Rauzi, F., C.L. Fly, and E.J. Dyksterhuis. 1968. Water intake on midcontinental rangelands as influenced by soil and plant cover. USDA Tech. Bull. 1390.

Rhoades, E.D., L.F. Locke, H.M. Taylor, and E.H. MeIlvain. 1964. Water intake on a sandy range as affected by 20 years of differential cattle stocking rates. J. Range Manage. 17:185-190.

Sims, P.L., R.E. Sosebee, and D.M. Engle. 1982. Plant and vegetation responses to grazing management, p. 4-31. In: D.D. Briske and M.M. Kothmann (eds.), Proc., A National Conference on Grazing Management Technology, Texas A\&M Univ., College Station.

Skovlin, J.M., R.W. Harris, G.S. Strickler, and G.A. Garrison. 1976. Effects of cattle grazing methods on ponderosa pine-bunchgrass range in the Pacific Northwest. USDA Forest Serv. Tech. Bull. 1531.

Smeins, F.E. 1977. Influence of vegetation management on yield and quality of surface runoff. Texas A\&M Univ., Texas Water Resources Institute.

Smeins, F.E., T.W. Taylor, and L.B. Merrill. 1976. Vegetation of a 25-year exclosure on the Edwards Plateau, Texas. J. Range Manage. 29:24-29.

Smith, D.R. 1967. Effects of cattle grazing on a ponderosa pine-bunchgrass range in Colorado. USDA Tech. Bull 1371.

Snedecor, G.W., and W.G. Cochran. 1971. Statistical Methods. Iowa State Univ. Press, Ames.

Thurow, T.L., W.H. Blackburn, and C.A. Taylor, Jr. 1986. Hydrologic characteristics of vegetation types as affected by livestock grazing systems, Edwards Plateau, Texas. J. Range Manage. 39:505-509.

Thurow, T.L., W.H. Blackburn, and C.A. Taylor, Jr. 1987. Rainfall interception losses by midgrass, shortgrass, and live oak mottes, J. Range Manage. 40:455-460.

Thurow, T.L., W.H. Blackburn, and C.A. Taylor, Jr. 1988. Some vegetation responses to selected livestock grazing strategies, Edwards Plateau, Texas. J. Range Manage. 41:108-114.

Walkley, A. and A.I. Black. 1934. An examination of the Deqtjareff method for determining soil organic matter and a proposed modification of the chromic acid titration method. Soil Sci. 37:29-38.

Warren, S.D., T.L. Thurow, W.H. Blackburn, and N.E. Garza. 1986a. The influence of livestock trampling under intensive rotation grazing on soil hydrologic characteristics. J. Range Manage. 39:491-495.

Warren, S.D., M.B. Neville, W.H. Blackburn, and N.E. Garza. 1986b. Soil response to trampling under intensive rotation grazing. Soil Sci. Soc. Amer. J. 50:1336-1341.

Wood, M.K., and W.H. Blackbum. 1981. Grazing systems: Their influence on infiltration rates in the rolling plains of Texas. J. Range Manage. 34:331-335.

MOVING? Send us your new address as soon as you know it to keep journals coming to you. Our new address is SRM, 1839 York St., Denver, CO 80206. 